\title{
SOCIOECONOMIC FACTORS INFLUENCING THE CHOICE OF TYPE OF BROILER ENTERPRISE AMONG POULTRY FARMERS IN DELTA STATE NIGERIA
}

\author{
P.C. IKE $^{1}$ and V.U. OBOH ${ }^{2}$ \\ ${ }^{1}$ Department of Agricultural Economics and Extension, Delta State University, Asaba Campus, \\ Asaba, Nigeria \\ ikepeecee@yahoo.com \\ ${ }^{2}$ Department of Agricultural Economics, University of Agriculture, Makurdi, Nigeria
}

\begin{abstract}
This paper specifically examined the socioeconomic characteristics of the broiler farmers that influence the choice of type of broiler enterprise and as well determined the output of poultry farmers in the study area. This is with a view to improving broiler production in Nigeria. A multistage sampling procedure was adopted in selecting broiler farmers for the study. A total of 80 respondents were interviewed for the study but 76 copies of questionnaire, comprising 35 Brood-and-sell farmers and 41 Brood-and-finish farmers were utilized for analysis. Data were analysed using descriptive statistics, budgetary technique, multiple linear regressions and the logit model. Findings revealed that while it cost $\$ 49,320.00$ ( $\$ 43,200.00$ variable cost and $\$ 6,120.00$ fixed cost) to raise a 500 broiler unit to four weeks for those practicing Brood-and-sell, it took $\$ 410,070.00$ (\$394,870.00 variable cost and \#15,200.00 fixed cost) to raise same unit of 500 broilers to maturity at 10 weeks for the Brood-and-finish enterprise. Return on Investment (RI) for Brood-and-Sell broiler enterprise was 0.62 while that of Brood-and-finish Broiler enterprise was 0.58. This indicates that a one naira investment in Brood-and-Sell enterprise realized a profit of $62 k$ while that of Brood-and-finish enterprise realized 58k implying that on the basis of this analysis, the Broodand-Sell broiler enterprise is more profitable than the Brood-and-finish broiler enterprise in the study area. The parameter estimates showed that six variables significantly influence the choice of the techniques. These include household size, education, farm size, cost of feed, cost of medication and access to credit.

Key words: Brood-and-sell, Brood-and-finish, Budgetary technique, Return on investment
\end{abstract}

\section{INTRODUCTION}

One of the major developmental challenges facing most developing countries is their inability to adequately feed their ever increasing population with the right proportion of calories and protein. The nutritional status of many Nigerians is characterized by low calorie and protein intake. Most animal proteins are delicious but not easily affordable. Animal protein sources include fish, egg, poultry meat, beef, milk, bacon, chevron, pork and mutton. The three most popular are frozen fish, beef and poultry egg and meat.

Poultry production has become a full time job for many and is considered to be a commercial viable enterprise contributing significantly to Gross Domestic Product (GDP). The environments to which poultry birds are exposed include the housing system, the feed they consume, climatic factors and management systems. All these affect the performance of the birds. The problems associated with poultry production in Nigeria are low egg production, diseases and pests, low

Journal of the Faculty of Agriculture and Veterinary Medicine, Imo State University, Owerri www.imsu-jafs -info 
and poor performing breed, poor weight gain/feed conversion, feeding and management problems and lack of capital (Ike and Ugwumba, 2009).

Broilers are species of chicken which have been developed to put on flesh at a fast rate. They are usually not good layers because in their genetic development, there has been a systematic concentration of the characteristics for rapid growth rather than those of egg production (Obioha, 1992). A good broiler should attain mature weight of 1.0 to $1.5 \mathrm{Kg}$ in 7 to 8 weeks on the average (Obioha, 1992). Broilers are younger than layers relative to their size, less immune to disease, stock at high densities and therefore more susceptible to adverse effects of management error (Oluyemi and Roberts, 1979).

Broiler is an important aspect of poultry production in Nigeria. It supplies poultry meat which is one of the sources of protein available to Nigerians. In recent times broiler production has been greatly emphasized. This is because of the need to provide more protein to improve on the diet of the third world countries. Broilers have high conversion efficiency of feed to meat. At maturity a broiler dresses at about $1.5 \mathrm{Kg}$ carcass weight. This is equivalent to 1500 grammes of animal protein and this is sufficient to satisfy an adult human protein requirement for 23 days. It takes about 10 weeks to raise a broiler to slaughter weight and takes only about $4.5 \mathrm{Kg}$ feed (Evbuomowan, 2005). In addition to fast growth, attributes of the broilers which are of economic importance include good body conformation and ability to utilize relatively low quality feed and their low mortality (Oluyemi and Roberts, 1979).

The goal of any broiler farmer is to make profit, and profit level depends on the ability of the farmer to reduce the cost of inputs and on the management procedures. In recent years one of the major problems of the broiler industry in Nigeria has been the increase in production cost. This has led many small scale poultry farmers to resort either to brood-and-sell or to brood-and-finish enterprise with a view to reducing input cost, improving turnover of capital or increasing profitability.

Brood-and-sell refers to the system where a farmer broods a reasonable number of chicks for about $4-5$ weeks and then sells them to other farmers who fatten them to maturity. This method of nursing baby chicks and selling the infants is popularly called brood-and-sell. This system is advantageous to the farmer as the capital required for brooding one chick to four weeks of age is small so that a farmer can now have a bigger flock size with the same amount of capital. There is also the advantage of quick turnover of invested capital. On the other hand, brood-and-finish involves all the practices carried out in order to help bring up the chicks usually from day old till the time they have attained maturity which is between $10-12$ weeks of age. Profit is maximized in Brood-and-finish by a single farmer.

The choice of either Brood-and-sell or Brood-and-finish is controlled by available space, available capital and the farmer's experience. There is need therefore to study the two broiler production systems in Delta state in order to analyse the apparent advantages of the two 
enterprises over each other to find out how profitable each can be and under what circumstances any of them can be recommended. Consequently, this paper specifically examines the socioeconomic characteristics of the broiler farmers, analyses the determinants of output in broiler enterprise, and assess the socioeconomic factors that influence the choice of type of broiler enterprise among the poultry farmers in the study area. This is with a view to improving broiler output in Nigeria.

\section{MATERIALS AND METHODS}

\section{Study Area}

Delta state, the study area is one of the nine states of the Niger Delta in Nigeria. The state has a population of 4.1 million (NPC, 2006) with a total land area of 17,440 square kilometer, of which about one-third is swampy and water logged (Delta State Diary, 2003). It is composed of 25 local government areas (LGAs) divided into three agricultural zones of Delta north, Delta central and Delta south. The state is currently the largest producer of petroleum products in the country. However, agriculture is the dominant aspect of her rural economy.

\section{Sampling/Data Collection}

A multistage sampling procedure was adopted in selecting broiler farmers for the study. Nine LGAs were randomly selected (3 from each agricultural zone) for the study. A list of registered broiler farmers in the nine selected LGAs was compiled to form the sampling frame. The broiler farmers were stratified into Brood-and-sell and Brood-and-finish farmers. Between 4 and 9 broiler farmers were randomly selected from each of the sampled LGAs depending on the number of the farmers in each stratum. A total of 80 respondents were interviewed for the study but 76 copies of questionnaire, comprising 35 Brood-and-sell farmers and 41 Brood-and-finish farmers, were suitable for analysis. Information collected include farmer's socioeconomic characteristics such as age, farming experience, gender, household size and level of education; resource and production characteristics which include farm size (number of birds), cost of drugs and veterinary care and mortality rate; institutional and technology attribute such as membership of cooperative society, distance to source of feeds, access to agricultural credit and extension visits.

\section{Data Analysis}

Data were analysed using descriptive statistics, budgetary technique, multiple linear regressions and the logit model. Descriptive statistics involved the use of frequency counts, percentages and means to describe the socioeconomic variables in the study, while the budgetary technique was used to establish the profitability of Brood-and-sell and Brood-and-finish production techniques. The specifications of the budgetary technique, multiple regression model and logit technique are as follows: 


\section{Budgetary technique}

The budgetary technique was employed to compute the net profit as well as return per unit of investment (RI) for Brood-and-sell and Brood-and-finish broiler techniques as follows: Gross Margin $(\mathrm{GM})=$ Gross Revenue $(\mathrm{GR})-$ Total variable cost $(\mathrm{TVC})$

Where, Total cost $(\mathrm{TC})=$ Total fixed cost $(\mathrm{TFC})+$ Total variable cost $($ TVC $)$.

Profit $(\pi)=$ Gross margin (GM) - Total fixed cost (TFC) (Horton, 1982).

Variable inputs include cost of Day-old chicks, feeds, labour, drugs, transportation and other incidentals including depreciation on fixed items. The monetized values of these inputs were deducted from the gross revenue (GR) to compute the gross margin (GM) for broiler farmers using each of the two systems. The net profit was computed by deducting the fixed costs (such as costs of housing, drinkers wheel barrows and other fixed items) from the gross margin, while return per unit of investment ( $)$ was calculated by finding the ratio of the net profit to the total cost of production; $\mathrm{RI}=\pi / \mathrm{TC}$.

\section{Multiple Regression Model}

The multiple regressions were used to analyse the socioeconomic determinants of output in broiler enterprise. The model is implicitly specified as:

$\mathrm{Yi}=\mathrm{f}(\mathrm{Xi})+\mu$

The model was explicitly specified in three functional forms of linear, semi logarithm, and double logarithm (Pindyke and Rubinfeld, 1997; Gujarati, 2006):

Linear: $Y=b_{0}+b_{1} X_{1}+b_{2} X_{2}+b_{3} X_{3}+b_{4} X_{4}+b_{5} X_{5}+\ldots+b_{9} X_{9}+b_{10} X_{10}+\mu$

Semi-log model: $\mathrm{Y}=\log \mathrm{b}_{0}+\mathrm{b}_{1} \log \mathrm{X}_{1}+\mathrm{b}_{2} \log \mathrm{X}_{2}+\mathrm{b}_{3} \mathrm{Og} \mathrm{X}_{3}+\mathrm{b}_{4} \log \mathrm{X}_{4}+\mathrm{b}_{5} \log \mathrm{X}_{5}+$ $\mathrm{b}_{6} \log \mathrm{X}_{6}+\mathrm{b}_{9} \log \mathrm{X}_{9}+\mathrm{b}_{10} \log \mathrm{X}_{10}+\mu$

Double $\log$ model: $\log \mathrm{Y}=\log _{0}+\mathrm{b}_{1} \log \mathrm{X}_{1}+\mathrm{b}_{2} \log \mathrm{X}_{2}+\mathrm{b}_{3} \mathrm{og} \mathrm{X}_{3}+\mathrm{b}_{4} \log \mathrm{X}_{4}+$ $\mathrm{b}_{5} \log \mathrm{X}_{5}+\mathrm{b}_{9} \log \mathrm{X}_{9}+\mathrm{b}_{10} \log \mathrm{X}_{10}+\mu$

where $\mathrm{Y}=$ Broiler output $(\mathrm{Kg})$

$\mathrm{X}_{1}=$ Age of farmers in years, $\mathrm{X}_{2}=$ Farming experience, $\mathrm{X}_{3}=$ Family size

$\mathrm{X}_{4}=$ Labour (Mandays), $\mathrm{X}_{5}=$ Educational attainment measured in the number of years spent in formal education, $X_{6}=$ Gender (Dummy variable: female $=1$, male $=0$ ), $X_{7}=$ Access to credit (Dummy variable: 1 if credit was accessed, 0 if otherwise), $\mathrm{X}_{8}=$ Farming status (Dummy variable: 1 if full time farmer, 0 if otherwise, $X_{9}=$ Number of day old chicks, $X_{10}=$ Quantity of feeds $(\mathrm{Kg}), \mu=$ Stochastic random term.

The lead equation was chosen on the basis of conformity with a priori expectations of parameters, statistical as well as econometric criteria such as the magnitude of $\mathrm{R}^{2}$ and the $\mathrm{t}$ values of the estimates and the number of significant variables in each estimated equation.

The a priori expectations of the signs of the regression coefficients are: $b_{1}>0 ; b_{2}>0 ; b_{3}>0$; $b_{4}>0 ; b_{5}><0 ; b_{6}>0 ; b_{7}>0 ; b_{8}>0 ; b_{9}>0 ; b_{10}>0$ 


\section{The logit regression model on choice of broiler enterprise technique}

In order to analyse the socioeconomic factors that determine the broiler farmer's choice for adoption of Brood-and-sell or Brood-and-finish technique, there is need to employ a model that deals with the dichotomous dependent variable "Brood-and-sell" or "Brood-and-finish". The relationship of this behavioural dependent variable can be examined with that of the independent variables. However, such models cannot be estimated by either multiple regression or the ordinary least square (OLS) techniques. While multiple regression technique results in invalid parameter estimates and wrong magnitude of the effects of the independent variables on the dependent variables, the OLS assumptions that the variances of the error terms are constant and not correlated with the level of independent variables are violated.

Nonetheless, four commonly used approaches to estimate such models include: the Linear probability model (LPM), Logit model, Probit model and the Tobit model (Gujarati, 2006). The LPM is not generally recommended because it provides predicted values that may fall outside the 0-1 interval, thus violating the assumptions of probability. Logit, Probit and Tobit models give maximum likelihood estimates and overcome most of the shortcomings of LPM by providing consistent and efficient estimates. The Logit model framework is however preferred among the other three models because it has been found to be efficient in explaining such dichotomous decision variables (Gujarati, 2006).

In formulating the model, $\mathrm{Pi}$ is assumed to be the observed response of farmer I (i.e. $\mathrm{Pi}=1$ for broiler farmer who chooses Brood-and-sell technique, and $\mathrm{Pi}=0$ for a farmer who does not operate Brood-and-sell technique). The decision to choose Brood-and-sell technique by the ith farmer depends on $\mathrm{Xi}$, which is a vector of factors representing socioeconomic factors. The disturbance term is represented by $(\varepsilon)$ and assumed to have a zero mean.

Conceptually, the decision model can be stated as:

$$
\operatorname{In}\left(\frac{P i}{1-P i}\right)=\exists i+\sum_{j=i}^{n} \exists j X j i+\varepsilon
$$

The empirical model specifying the choice of production technique by the ith broiler farmer is implicitly stated as:

$$
\operatorname{In}\left(\frac{P i}{1-P i}\right)=\exists_{0}, \exists_{1} X_{1}, \exists_{2} X_{2}, \exists_{3} X_{3}, \exists_{4} X_{4}, \exists_{5} X_{5}, \exists_{6} X_{6}, \exists_{7} X_{7}, \exists_{8} X_{8}, \exists_{9} X_{9}, \exists_{10} X_{10}, \varepsilon
$$

Where, $\mathrm{X}_{\mathrm{i}} \mathrm{s}$ are the explanatory variables as contained in Table 1 
Table 1: Description of Variables in the Model

\begin{tabular}{ll}
\hline Variable & Description and Unit \\
\hline Age & Age of farmers; (years) \\
Gender & Farmer's sex; (Dummy: male 1, female 0) \\
Eousehold size & Number of household members \\
Farm size & Number of years spent on formal education \\
Cost of feed & Number of birds stocked \\
Cost of medication & Cost of feed purchased \\
Extension contacts & Amount spent on drugs/veterinary services \\
Credit & Access to extension advice (Dummy) \\
Labour & Access and amount of credit obtained \\
\hline
\end{tabular}

\section{Results and Discussion}

\section{The socioeconomic characteristics of poultry farmers in Delta state, Nigeria}

The socioeconomic characteristics of broiler farmers practicing Brood-and-sell and Brood-andfinish techniques are shown in Table 2.

The broiler production system is dominated by middle aged male and female farmers with more males than females in the two enterprise production techniques. The farm sizes with respect to the number of birds indicate that the brood-and-sell technique stock more birds at a time when compared with the brood-and-finish technique (Table 2). Respondent's level of education indicates a higher level of educational attainment by farmers involved in the brood-and-finish method. Cost of feed was more in the brood-and-finish technique while cost of medication was higher in the brood-and-sell technique. The level of extension contact to both categories of broiler farmers was low while labour cost was higher in the brood-and-finish technique. Though most of the respondents belonged to social organizations, almost less than half of the farmers in both techniques did not enjoy access to credit for their broiler production activities.

Table 2: Summary of Socioeconomic characteristics of broiler farmers practicing Brood-and-sell and Brood-and-finish techniques

\begin{tabular}{|c|c|c|}
\hline Variable & Brood-and-sell $(n=35)$ & Brood-and-finish $(n=41)$ \\
\hline Age (years) & 39.0 & 41.0 \\
\hline Gender ( $\%$ male $)$ & 59.0 & 77.0 \\
\hline Household size & 6.0 & 8.0 \\
\hline Education (No. of years) & 9.0 & 12.0 \\
\hline Farming experience (years) & 9.0 & 15 \\
\hline Farm size (number of birds) & 2000 & 980 \\
\hline Cost of feed ( $\left.\sharp^{\prime} 000\right)$ & 33.5 & 359.45 \\
\hline Cost of medication ( $\left.\mathbb{N}^{\prime} 000\right)$ & 2.2 & 10.22 \\
\hline Extension contacts $(\%)$ & 22.0 & 12.4 \\
\hline Access to Credit (\%) & 47.8 .0 & 49.0 \\
\hline Labour ( $\left.\mathbb{N}^{`} 000\right)$ & 4.2 & 8.5 \\
\hline
\end{tabular}




\section{Computation of net returns to broiler production}

The costs and returns to broiler production using the brood-and-sell and brood-and-finish techniques are shown in Table 3. For all the cost and revenue items considered in the budgetary analysis, the brood-and-finish technique recorded higher estimates with significant variations found in the estimates obtained for the two techniques. Opening stocks of 500 birds were used for analysis in both enterprise techniques. A Day-old chick costs $\$ 8.00$. Findings revealed that while it costs $\$ 49,320.00$ ( $\$ 43,200.00$ variable cost and $\$ 6,120.00$ fixed cost) to raise a 500 broiler unit to four weeks for those practicing Brood-and-sell, it took $\$ 410,070.00$ ( $\$ 394,870.00$ variable cost and $\$ 15,200.00$ fixed cost) to raise same unit of 500 broilers to maturity at 10 weeks for the Brood-and-finish enterprise.

With a selling price of $\$ 160.00$ per broiler raised for four weeks in the Brood-and-sell method and providing for a $2 \%$ mortality rate, the gross sales gave $\$ 78,400.00$ with a gross margin of $\$ 36,700.00$ and a net farm income of $\$ 30,580.00$. In the same vein, providing for a mortality rate of $3 \%$ and at a selling price of $\$ 1,300.00$, the Brood-and-finish enterprise realized a gross sales of $\$ 649,500.00$ with a gross margin of $\$ 254,630.00$ and a net farm income of $\$ 239,430.00$.

From the above information, the Return on Investment (RI) for Brood-and-Sell broiler enterprise is 0.62 while that of Brood-and-finish Broiler enterprise is 0.58 . This indicates that a one naira investment in Brood-and-Sell enterprise realizes a profit of $62 \mathrm{k}$ while that of Brood-and-finish enterprise realize 58k implying that on the basis of this analysis, the Brood-and-Sell broiler enterprise is more profitable than the Brood-and-finish broiler enterprise in the study area.

\section{Determinants of Output in Broiler Enterprise}

On the basis of an expected relationship between broiler output and the socioeconomic variables of the poultry farmers, a multiple regression analysis was used to ascertain the influence of these variables on broiler output in the study area. These socioeconomic characteristics of the farmers as earlier specified included, Age of farmers, Farming experience, Family size, labour (mandays), Educational attainment, Gender, Access to credit, Farming status, Number of day old chicks and Quantity of feeds. 
Table 3: Cost and returns to broiler production for brood-and-sell and broodand-finish techniques

\begin{tabular}{|c|c|c|}
\hline Items & Brood-and-sell $(\mathrm{n}=\mathbf{5 0 0})$ & Brood-and-finish $(\mathrm{n}=\mathbf{5 0 0})$ \\
\hline & (490 birds @ 2\% mortality) & 485 birds @ 3\% mortality \\
\hline Gross Income & 78,400 & $630,500.00$ \\
\hline Broiler sales (stock balance) & & - \\
\hline General stock & & - \\
\hline Empty bags (feeds) & 500 & $5,000.00$ \\
\hline Manure (bags) & 1,000 & $12,000.00$ \\
\hline Total Revenue & $79,900.00$ & $649,500.00$ \\
\hline \multicolumn{3}{|l|}{ Variable Cost } \\
\hline Opening stock & 4,000 & 4000 \\
\hline Feeds (Starter) & 33,500 & $97,650.00$ \\
\hline Feeds (Finisher) & - & $261,800.00$ \\
\hline $\begin{array}{c}\text { Medication/Veterinary } \\
\text { Services }\end{array}$ & 2,200 & $10,220.00$ \\
\hline $\begin{array}{l}\text { Miscellaneous (water, wood } \\
\text { shavings, electricity) }\end{array}$ & 1,000 & $5,350.00$ \\
\hline Labour & 2,500 & $15,850.00$ \\
\hline Total Variable cost & 43,200 & $394,870.00$ \\
\hline $\begin{array}{l}\text { Gross margin } \\
\text { Fixed Cost }\end{array}$ & $36,700.00$ & $254,630.00$ \\
\hline $\begin{array}{l}\text { Depreciation on } \\
\text { shelter/housing }\end{array}$ & 1,300 & $5,680.00$ \\
\hline Depreciation on equipment & 1,200 & $3,100.00$ \\
\hline $\begin{array}{c}\text { Depreciation on repairs and } \\
\text { maintenance of heat and } \\
\text { light }\end{array}$ & 2,420 & $4,420.00$ \\
\hline Transportation & 1,200 & $2,000.00$ \\
\hline Total Fixed Cost & 6,120 & $15,200.00$ \\
\hline Net Farm Income (NFI) & $30,580.00$ & $239,430.00$ \\
\hline $\begin{array}{l}\text { Return on Investment (RI) } \\
=\text { NFI/TC }\end{array}$ & 0.62 & 0.58 \\
\hline
\end{tabular}

The regression model was tried under the three basic functional forms and the semi logarithmic function was chosen as the lead equation. This is based on the value of the coefficient of multiple determination $\left(\mathrm{R}^{2}\right)$ and the number of significant variables in conformity with a priori expectations and the lowness of the mean square error. The econometric estimate is presented in Table 4. 
Table 4: Lead Equation of Regression Estimate (Semi-log) Results

\begin{tabular}{|c|c|c|}
\hline Variables & Coefficients & t-values \\
\hline Constant & 0.895 & $(8.84)^{* *}$ \\
\hline Age & 701.3 & $(0.744)$ \\
\hline Experience & 2.99 & $(5.94) * *$ \\
\hline Family size & $2.27 \mathrm{E}-02$ & $(0.79)$ \\
\hline Education & 4.21E-02 & $(0.83)$ \\
\hline Farming status & 0.11 & $(2.39)^{*}$ \\
\hline Gender & -0.21 & $(-1.23)$ \\
\hline Access to credit & $6.72 \mathrm{E}-06$ & $(3.95)^{* *}$ \\
\hline Labour (mandays) & $9.14 \mathrm{E}-07$ & $(4.29) * *$ \\
\hline Number of day old chicks & -0.08 & $(-2.24)^{*}$ \\
\hline Quantity of feeds & -0.09 & $(-2.56)^{*}$ \\
\hline $\mathrm{R}^{2}$ & \multicolumn{2}{|c|}{0.79} \\
\hline F- ratio & \multicolumn{2}{|c|}{39.1} \\
\hline
\end{tabular}

Figures in parenthesis are t-values: *Significant at 5\% level, **Significant at $1 \%$ level The regression estimates indicate that six variables viz: experience in poultry (broiler production), farming status, access to credit, labour, number of day old chicks and quantity of feeds were statistically significant on their influence on broiler output. The coefficient of multiple determination $\left(\mathrm{R}^{2}\right)$ of 0.79 indicates that about $79 \%$ of the changes in output of broiler were explained by the explanatory variables and the F-ratio of 39.1 is significant at 5 percent level.

Examining the coefficient of individual characteristics reveal that experience in poultry production is statistically significant at $1 \%$ level of significance. This implies that poultry output will increase as the farmers experience in poultry production increases. This is in line with the $a$ priori expectation as it is well known in economic theory that efficiency increases with an increase in production experience. The size of the household of the farmer, though positive is not significant on its effect on output. This may be as a result of the fact that most of the family members are engaged in other forms of enterprises rather than serving as a source of labour to the poultry business. In the same vein, level of formal educational attainment is not significant. This could be that experience acquired on the job training may prove to be more relevant in affecting broiler output than acquisition of mere formal education. Though, relevant as formal education is, it can not substitute experience in a particular enterprise.

The farming status of the broiler producers has positive influence on output and it is statistically significant at $5 \%$ level. This implies the more a farmer is devoted to poultry production on full time basis, the more the possibility of improving output. This is in line with a priori expectation as a full time poultry farmer is expected to specialize and get more experience than the part time farmers who have their time to share with other activities. 
The coefficient of access to farming credit is also positive and significant at $1 \%$ level. This implies that the more the broiler farmers access credit the more their output would be as more day old chicks will be bought and more labour can be employed. This finding is also in line with those of various authors that credit is a veritable tool that can lead to increased output if properly applied (Ike and Chidebelu, 2003; Saito, 1994). In the same vein, labour as a critical input in production is positive and significant at $1 \%$ level. With adequate hands, output will increase relative to the size of the farm.

The coefficient of number of day old chicks is negative but significant at $5 \%$ level. Though this is against the a priori expectation, the implication could be that as more day old chicks are bought, mortality rate could become high particularly with poor management. Likewise, the quantity of feed is negative and significant at 5\% level. This could imply that farmers are using low feeds of low quality for their broiler production. The quality feeds have very high effect on output.

\section{Logit regression model}

The LIMDEP Package was used to estimate the empirical model using the maximum likelihood

estimation method. The $\chi^{2}$ goodness of fit test statistics show that the model is significant at the $5 \%$ level (Table 5 and this suggests that the included explanatory variables in the model are relevant in explaining the decision to choose either of the two broiler production techniques. The parameter estimates show that six variables significantly influence the choice of the techniques. These include household size, education, farm size, cost of feed, cost of medication and access to credit. However, three variables among the significant ones are negatively signed. These are household size, education and access to credit while farm size, cost of feed and cost of medication are positively signed.

The positive and significant coefficient of farm size shows that, holding other variables constant, if the farm size (number of birds stocked) increases by a unit, on the average, the logit or log of the odds in favour of adopting the Brood-and-Sell technique increases by 0.56 units. In other words the probability of adopting the Brood-and-Sell technique increases with increase in farm size i.e. the number of birds stocked and vice versa for Brood-and-finish technique. require increase in other fixed inputs and this will propel farmers to adopt the practice of Brood-and-Sell to avoid going through the pressure that Brood-and-finish will give them. In the same vein a unit increase in the cost of feed and cost of medication will lead to 0.21 units and 2.20 unit increases respectively in the probability of adoption of the Brood-and-Sell technique. 
Table 5: Parameter estimates of the logit model of broiler farmer's choice of Production technique

\begin{tabular}{|l|c|c|}
\hline Variable & Parameter estimate & Standard error \\
\hline Constant & $7.5160^{* *}$ & 3.2341 \\
Age & 0.3542 & 0.2987 \\
Gender & 0.4921 & 0.4608 \\
Household size & $-0.4628^{*}$ & 0.2274 \\
Education & $-0.3216^{*}$ & 0.1265 \\
Farm size & $0.5623^{*}$ & 0.2914 \\
Cost of feed & $0.2125^{*}$ & 0.0852 \\
Cost of medication & $2.2045^{*}$ & 1.0903 \\
Extension contact & 1.2563 & 0.9879 \\
Access to credit & $-0.1487^{*}$ & 0.0523 \\
Labour & 2.3691 & 2.0048 \\
Log likelihood function & -201.365 & \\
$\chi^{2}$ & $78.25^{*}$ & \\
\hline \multirow{2}{*}{$* *$ Significant at $1 \%$ and $5 \%$ levels respectively } & \\
\hline
\end{tabular}

(Dependent variable $=$ Brood-and-sell 1, 0 for Brood-and-finish).

This is in line with the a priori expectation as an increase with the number of birds will On the other hand, a unit increase in the number of household will lead to a 0.46 unit decrease in the probability of adopting the Brood-and-Sell technique. This could be explained on the basis that as the household size increases, there is availability of free labour that can be mobilized in the Brood-and-finish broiler technique which requires more labour. Also, an increase in educational attainment of the farmers' decreases by 0.32 units the probability of adopting the Brood-and-Sell technique and this could be explained that a well educated farmer is better poised to face all the challenges that might arise in the Brood-and-finish technique and hence will opt to raise his or her broilers from day-old to maturity. Finally, when the farmers have access to financial credit, the possibility of adopting the Brood-and-Sell technique decreases by about 0.15 units and it implies that with access to credit, broiler farmers will adopt the technique of rearing their birds from day-old to point of maturity.

\section{Conclusion}

This study revealed that among other variables, experience and access to agricultural credit exerted significant influence on output in broiler enterprise. The Brood-and-Sell and Brood-andfinish are two broiler production techniques that could be adopted and practiced by the farmers as both are profitable enterprises. It is recommended that policy measures to improve the experience of practicing farmers as well as increased access to credit should be advocated by all the tiers of government in Nigeria. 


\section{References}

Evbuomowan, G. (2005) "Empirical Analysis of Cost and Returns to Commercial Table Egg Production in Lagos state" A Paper at the Farm Management Association of Nigeria (FAMAN) $19^{\text {th }}$ Annual Conference, held at Delta state University, Asaba Campus, $18^{\text {th }}$ to $20^{\text {th }}$ October.

Gujarati, D. (2006), Essentials of Econometrics. Second edition. New York: McGraw Hill International Editions

Horton, D. (1982), "Partial Budget Analysis for On-farm Potato Research" Technical Information Bulletin. International Potato Centre, Lima. Peru Pp 16

Ike P.C. and C.O.A. Ugwumba (2009) "Profitability of small Scale Broiler Production in Onitsha North Local Government Area of Anambra State" International Journal of Poultry Science 8 (1)

Ike, P.C. and S.A.N.D. Chidebelu (2003), "Analysis of the Influence of Socioeconomic Variables on Economic Performance of Women Small Scale Business Enterprises in Nigeria: The Case of the Restaurant Industry in Enugu State, Journal of Home Economics Research, 5 (1): 44-51

Obioha, F.C. (1992). A Guide to Poultry Production in the Tropics. Acena Publisher Enugu. Pp 5 $-8$

Oluyemi J.A. and F. A. Robert (1999). Poultry Production in Warm Wet Climate Macmillian Press Ltd. London. Pp 14 - 20

Pindyck, R.S. and D.L. Rubinfeld (1977), Econometric models and economic forecasts. Second edition. New York: McGraw Hill International Editions Pp 298-329

Saito, K. (1994) "Raising the Productivity of Women in Sub - Saharan Africa". World Bank Discussion Paper No. 230 Washington D.C World Bank 